\title{
One way ahead for British biotechnology?
}

BRITISH biotechnology may yet survive. A plan by three renowned molecular biology laboratories for setting up in Britain a commercial biotechnology venture is being considered by several agencies of the British government.

The laboratories concerned are the MRC Laboratory of Molecular Biology at Cambridge, the Laboratories of the Imperial Cancer Research Fund in London and the Cold Spring Harbor Laboratory on Long Island in the United States. The three principals are Dr Sydney Brenner, Dr Walter Bodmer and Dr J. D. Watson, the respective directors of the three laboratories.

The essence of the plan is to establish a small organisation in Cambridge, initially for the preparation and supply on commercial terms of monoclonal antibodies, principally for use in biomedical investigations.

This would involve exploiting a technique originally developed by Dr César Milstein of the Laboratory of Molecular Biology, Cambridge, in which lymphocytes producing antibodies of a specific kind are fused with cells of cancerous lymphoma tissue.

After suitable selection procedures, the outcome can be a line of cells with the vigour of lymphoma cells which nevertheless produce the specific antibody prolefically.

This particular plan has emerged over the past year, and thus in its origins predates the Spinks Report on biotechnology, published at the beginning of April (Nature, 10 April and 24 January). That urged that the research councils and the public sources of venture capital in Britain, especially the National Research Development Corporation and the National Enterprise Board, should take steps to promote a British biotechnology industry. Both organizations have announced their interest in the field (Nature, 29 May).

The production of monoclonal antibodies has presumably been chosen as a first objective because it could be applied immediately, thus providing a new venture company with some bread and butter. The initial need of capital would be correspondingly modest.

The next steps to be taken in the setting up of a commercial venture are by no means obvious. The Medical Research Council, the obvious sponsor of such a venture, is precluded by its terms of reference from risking the loss of money. The NRDC is used to dealing with particular products and inventions, not with backing companies as such.

On the face of things, the National Enterprise Board is constitutionally better able to provide the backing a venture like this would need. One intriguing possibility is that the two private laboratories - Cold Spring Harbor and the Imperial Cancer

Research Fund - would be able to provide some of the capital if their boards of trustees agreed.

A spokesman for the National Enterprise Board declined this week to say whether his board was considering this particular proposal, but reaffirmed the organization's concern with biotechnology. It is, however, understood that

\section{Research councils}

\section{Disquiet over NERC succession}

THE appointment of Sir Hermann Bondi as full-time chairman of the UK Natural Environment Research Council (Nature, $15 \mathrm{May}$ ), although widely welcomed, is also the cause of consternation. At its meeting last week ( $28 \mathrm{May})$, the Council was sore that it had not been even formally consulted and concerned that the forced resignation of $\mathrm{Mr} \mathrm{R} \mathrm{J} \mathrm{H}$ Beverton, secretary of the council for the past sixteen years, might be misinterpreted.

Members of the council agree with the chief objective of the change at the top that NERC should be put on the same footing as the other research councils, with the responsibilities of chief executive and official accounting of ficer combined in the same person. Hitherto these functions have been the responsibility respectively of the Secretary and the Chairman, for the past three years Sir James Beament, head of the department of applied biology at the University of Cambridge.

What irks the council and dismays some of the directors of NERC research establishments is that when Sir Hermann's candidacy for the job became known to the Department of Education and Science early in April, both Beverton and Beament were presented with a fait accompli and, in effect, invited to go quietly. This, in the event, they both agreed to do.

The urgency of the decision stemmed from Sir Hermann Bondi's impending retirement as Chief Scientific Adviser to the Department of Energy with effect from Beverton out . . .

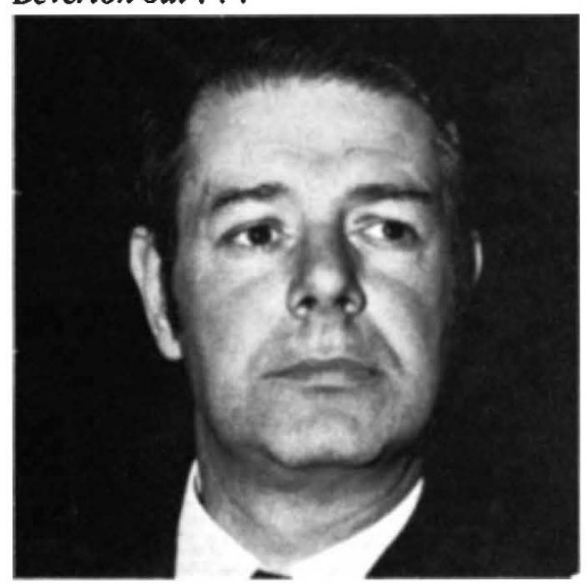

some news of the NEB's interest in the field will be forthcoming within weeks rather than months.

Much may depend on whether biotechnology is able to avoid the Catch-22 problem which has beset micro-electronics (see page 346, this issue) - if it's not good, it's not worth backing; if it is, why doesn't the market step in?
1 October, required by Civil Service rules on age. The NERC Council was left with the impression that if the succession at NERC had not been settled quickly and to his satisfaction, Bondi would have taken his undoubted talents elsewhere.

The past few years have seen something of a change in the character of NERC's programme. Although NERC continues to spend its own funds on a programme of basic research not markedly different from in the past, funds awarded to NERC by government departments for contract research ('Rothschild money') have increasingly emphasized energy-related problems - radioactive waste disposal and physical oceanography related to the exploration of the North Sea, for example.

Although the division of the responsibil-

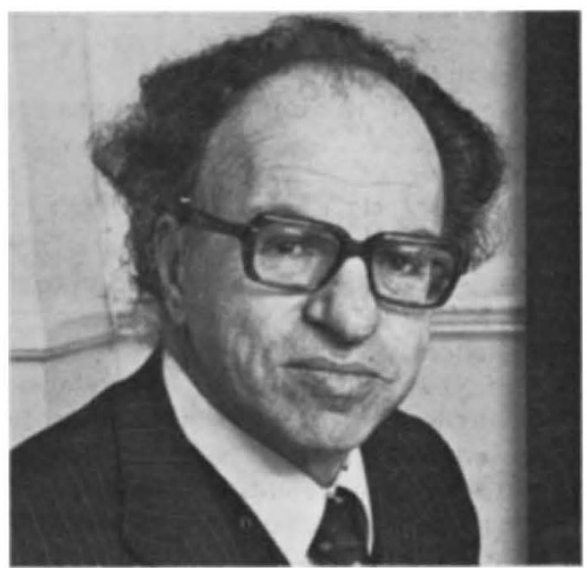

Bondi in

ities of chief executive and accounting officer is agreed to be the long-term reason for change, the move of the NERC headquarters from London to Swindon has complicated the problems of management in the past two years. Sir James Beament, based at Cambridge, has been spending two days a week on NERC business but has been hard-pressed to divide this time between London and Swindon.

Even so, there are many who consider that some role could have been found in the new organisation for $\mathrm{Mr}$ Beverton, who has only two years to go to his normal retirement date.

The council was at pains to emphasise at 